\title{
Kepuasan Jama'ah Haji Dalam Proses Pelayanan Haji (Studi Kasus Di Kabupaten Kuantan Singingi)
}

\author{
Bahrul Aswandi \\ Universitas Islam Negeri Sultan Syarif Kasim Riau \\ Email: bahrulaswandi@gmail.com
}

\begin{abstract}
Penelitian ini bertujuan untuk mengetahui; bagaimana Kepuasan Jama'ah Haji dalam Proses Pelayanan Haji Di Kabupaten Kuantan Singingi tahun 2016, dan untuk mengetahui apa saja faktor-faktor yang mempengaruhi Kepuasan Jama'ah Haji dalam Proses Pelayanan Haji Di Kabupaten Kuantan Singingi tahun 2016. Penelitian ini merupakan penelitian kualitatif dengan jumlah populasi berjumlah 300 orang. Karena populasinya lebih dari 100 , maka diambil $10 \%$ dari jumlah populasi yakni sebanyak 30 orang jama'ah yang akan diteliti. Teknik pengambilan sampel dengan menggunakan proportionate stratified random sampling (sampel acak dan berstrata secara proporsional). Berdasarkan hasil olahan data tentang maka dapat diketahui kepuasan jama'ah haji dalam proses pelayanan haji di Kabupaten Kuantan Singingi adalah "Sangat Puas" mencapai 83.82\%, baik dari segi pengolaan ibadah haji pada hakikatnya merupakan bentuk pelayanan kepada masyarakat. Dalam kaitan pengelolaan ibadah haji ada tiga bentuk pelayanan yang mesti di berikan, yakni pelayanan pembinaan manasik haji baik sebelum dan sesudah penyelenggaraan ibadah haji, pelayanan transportasi, pelayanan pemondokan, ktering, dan kesehatan. Faktor-faktor yang mempengaruhi ibadah haji terhadap pelaksanaan ibadah haji (Studi kasus di kabupaten Kuantan Singingi) Jasa yang diharapkan/dirasakan (expected service) : perasaan senang dalam merasakan pelayanan yang baik atau harapan-harapan nasabah terpenuhi. Terdapat sepuluh factor utama yang mempengaruhi harapan pelanggan terhadap suatu jasa yaitu (1) enduring service intensifiers, berupa harapan yang di sebabkan oleh orang lain dan filosofi pribadi seseorang mengenai suatu jasa; (2) kebutuhan pribadi, meliputi kebutuhan fisik, social, dan psikologis; (3) transitory service intensifiers, terdiri atas situasi darurat yang membutuhkan jasa tertentu (seperti asuransi kesehatan dan asuransi kecelakaan) dan jasa terakhir yang pernah dikonsumsi pelanggan; (4) persepsi pelanggan terhadap tingkat layanan perusahaan lain; (5) self-perceiped service role, yaitu persepsi pelanggan terhadap tingkat keterlibatannya dalam proses penyampaian jasa; (6) faktor situsional yang berada diluar kendali penyedia jasa; (7) janji layanan eksplitit, baik berupa iklan, personal selling, perjanjian maupun komunikasi dengan karyawan penyedia jasa; (8) janji layanan implisit, yang tercermin dari harga dan sarana pendukung jasa; (9) word of mouth, baik dari teman, keluarga, rekan kerja pakar maupun publikasi media massa; dan (10) pengalaman masa lampau.
\end{abstract}

\section{Key Words: Kepuasan; Jama'ah Haji; Pelayanan Haji Kuantan Singingi}

\section{PENDAHULUAN}

Islam adalah agama Allah SWT

yang diwahyukan kepada Nabi

Muhammad SAW sebagai agama terakhir dan merupakan nikmat Allah yang paling sempurna yang menjadi pedoman hidup umat manusia sepanjang sejarah. Sebagai muslim wajib 
meyakini dan menjalankan Rukun Islam. Salah satu kewajiban dalam Rukun Islam adalah menunaikan ibadah haji bagi yang mampu. Mampu disini diartikan adalah kemampuan fisik, harta, mental, dan kemampuan pada waktu seseorang hendak mengerjakan haji.

Sebagai seorang muslim harus meyakini dan mentaati, seta mengimani bahwa haji merupakan sebuah kewajiban yang wajib dikerjakan bagi yang sanggup dan mampu. Hal ini sesuai firman Allah dalam surah Ali imran ayat 97 .

Oleh karena itu, segala macam hambatan yang dihadapi umat Islam akan menghadapinya dengan penuh keikhlasan dan penuh kesabaran. Walaupun menempuh perjalanan antar negara, melelahkan, meninggalkan keluarga, penuh pengorbanan dan penuh resiko secara fisik dan mental serta harus mengeluar kan biaya yang relatif besar dan berat bagi masyarakat akan tetapi setiap tahun umat muslim di dunia berbondong bondong datang ke baitullah untuk melaksanakan Ibadah haji demi menjalankan kewajibanya sebagai seorang muslim.

Umat muslim sangat menyakini bahwa mengerjakan Haji dengan sungguh sungguh dan penuh keikhlasan, kesabaran serta hanya semata-mata mengharap ridho Allah akan mendatangkan keberkahan dan balasannya adalah Surga. Haji yang mabrur tiada upahnya kecuali surga. Walaupun sudah mengeluarkan bayak biaya dan bahkan ada yang menabung bertahun-tahun demi menjalaankan ibadah haji akan tetapi semangat umat muslim khususnya di Indonesia setiap tahunnya terus bertambah dan rela harus mengantri dalam daftar tunggu. Hal ini disebabkan disamping ingin memperoleh haji mabrur ada hal lain yang memotivasi untuk menjalankan ibadah haji yaitu dapat status sosial dari masyarakat.

Perjalanan bangsa Indonesia dalam menyelenggarakan ibadah haji telah memberikan makna

yang sangat berarti bagi kehidupan kenegaraan secara keseluruhan. Dalam berbagai peristiwa baik sosial, budaya, ekonomi maupun poltik, para hujjaj memiliki peran yang sangat penting dalam memberikan motivasi dan membudayakan "kehidupan yang salih" di masyarakat, sehingga selalu diharapkan dapat memberi secercah titik terang dalam kehidupan sosial kemasyarakatan. Beragamnya dimensi yang melingkupi penyelengga raan ibadah haji menyebabkan penanganan dan pengelolaan haji memiliki permasalahan yang sangat komplek dan sensitive (Ahmad Nidjam dan Alatief Hanam, 2001).

Dalam beberapa tahun terakhir jumlah jamaah Haji seluruh dunia mencapai sekitar dua hingga tiga juta orang. Jamaah Haji Indonesia selalu menempati peringkat lima besar dari keseluruhan jumlah jamaah haji, karena Indonesia merupakan negara yang mayoritas penduduknya beragama Islam dan kenyataan sejarah bahwa beberapa masyarakat Indonesia memiliki hubungan kekerabatan dengan bangsa arab (Ahmad Nidjam dan Alatief Hanam, 2001).

Indonesia sebagai salah satu negara yang memiliki jumlah penduduk beragama Islam terbesar di dunia, melakukan penyelenggaraan ibadah haji setiap tahunnya. Saat ini dasar dan payung hukum pelaksanaan penyelenggaraan ibadah haji berdasarkan pada Undang-undang Nomor 13 Tahun 2008 Tentang Penyelenggaraan Ibadah Haji. Dalam Undang-Undang Nomor 13 Tahun 2008 tentang Penyelenggaraan Ibadah Haji, mengatur mengenai rangkaian kegiatan pengelolaan pelaksanaan ibadah haji yang meliputi pembinaan, pelayanan, dan perlindungan jemaah haji.

Adapun tujuan Penyelenggaraan ibadah haji yaitu untuk memberikan pembinaan, pelayanan, dan perlindu 
ngan yang sebaik-baiknya bagi jemaah haji sehingga jemaah haji dapat menunaikan ibadahnya sesuai dengan ketentuan ajaran agama Islam. Penyelenggaraan ibadah haji dilaksana kan berdasarkan asas keadilan, profesionalitas, dan akuntabilitas dengan prinsip nirlaba. Dalam prakteknya, Undang-Undang Nomor 13 Tahun 2008 belum menjawab tuntutan dan harapan masyarakat karena substansi dan cakupannya

Dengan jamaah haji Indonesia yang cukup besar dan beragam profesi serta tingkat pendidikan jemaah haji menyebabkan tingginya kompleksitas pengorganisasian dan pelayanan sehingga pencapaian ukuran tingkat kepuasan jamaah haji sangat beragam dan bervariasi. Dalam Penyelenggaraan ibadah haji setiap tahun selalu ditemukan berbagai kritik dari berbagai kalangan yang disampaikan secara lisan maupun tertulis. Wacana yang selalu muncul ke permukaaan sebagian besar adalah ketidak puasan terhadap manajemen penyelenggaraan haji dan pelayanan yang dilaksanakan oleh pemerintah. Walaupun di sisi lain Pemerintah melalui berbagai inovasi dan penyempurnaan telah melakukan upayaupaya peningkatan baik dari aspek manajerial, sumber daya manusia, pola operasional, diversifikasi angkutan, diversifikasi pemondokan dan memberi kesempatan yang luas kepada masyarakat untuk berperan serta dalam penyelenggaraan haji (Ahmad Nidjam dan Alatief Hanam, 2001).

Akan tetapi dalam kenyataan dilapangan masih banyak dijumpai keluhan dan ketidakpuasan dari jamaah haji dalam hal pelayanan jamaah haji. Jamaah haji dalam hal pelayanan sering sekali mengeluh dalam hal masalah pemondokan, akomodasi, transportasi. Hal lain yang menjadi perhatian dan dikeluhkan jamaah haji dalam pengelolaan haji yaitu terkait keamanan, pada musim haji 2012, jumlah jamaah yang menjadi korban penipuan, pencurian, dan penjambretan meningkat. Pada tahun 2012 Jumlah kerugian yang dialami jamaah akibat aksi kriminalitas selama di Makkah mencapai Rp 267 juta dan 94.865 riyal Arab Saudi.

Hal ini mengakibatnya setiap tahun jamaah selalu mengeluh terhadap pelayanan jamaah. Di sisi lain Jamaah Haji ketika mengalami kerugian atas pelayananya, jamaah tidak pernah ada yang menggugat pihak pengelola pelaksanaan ibadah haji, karena beranggapan semua rangkaian ibadah haji adalah ibadah yang harus dijalankan dengan penuh keikhlasan dan kesabaran semata-mata karena mengharap ridho Allah. Padahal Jamaah Haji selaku konsumen mempunyai hak dalam hal perlindungan hukum apabila terjadi tindakan yang merugikanya. Munculnya keluhan dan ketidakpuasan dalam pelayanan serta kurangnya perlindungan hukum bagi jamaah haji selaku konsumen maka penulis tertarik mengangkat topik perlindungan hukum bagi jamaah haji.

\section{METODE}

Penelitian ini merupakan penelitian kualitatif dengan jumlah populasi berjumlah 300 orang. Karena populasinya lebih dari 100, maka diambil $10 \%$ dari jumlah populasi yakni sebanyak 30 orang jama'ah yang akan diteliti. Teknik pengambilan sampel dengan menggunakan proportionate stratified random sampling (sampel acak dan berstrata secara proporsional)

\section{HASIL DAN PEMBAHASAN Kepuasan Jamaah}

Menurut Engel, mengatakan bahwa kepuasan nasabah merupakan evaluasi purnabeli dimana alternatif yang dipilih sekurang- kurangnya sama atau melampui harapan pelanggan, sedangkan 
ketidakpuasan timbul apabila hasil tidak memenuhi harapan para pelanggan. Kepuasan adalah tingkat perasaan seseorang setelah membandingkan tingkat kinerja/hasil yang dirasakan dengan harapannya. Apabila kinerja di bawah harapan, maka nasabah akan kecewa tetapi apabila kinerja sesuai dengan harapan maka nasabah akan merasa sangat puas dengan kinerja karyawanKepuasan pelanggan telah menjadi bagian dalam misi dan tujuan sebagian besar perusahaan. Kepuasan pelanggan dirumuskan sebagai evaluasi purnabeli, dimana persepsi terhadap kinerja alternatif produk/jasa yang dipilih memenuhi atau melebihi harapan sebelum pembelian (Philip Kotler, 2010).

\section{Haji}

Secara bahasa haji berasal bahasa Arab haj atau hijj, yang berarti menuju atau mengunjungi tempat yang agung (Abd al-Rahman al-Jaziri, 2010). Dalam pengertian agama, haji adalah perjalanan menuju Mekkah untuk melaksanakan ibadah thawaf, sa'i, wukuf di Arafah, dan seluruh rangkaian manasik ibadah haji sebagai bentuk pelaksanaan perintah Allah dan dalam kerangka mencari ridha-Nya (AlSayyid Sabiq, 2004). Umrah secara bahasa berarti ziarah. Secara istilah, umrah berarti mengunjungi Ka'bah dan thawaf sekelilingnya, $s a^{\prime \prime} i$ antara bukit Shafa dan Marwah, serta mencukur atau memotong rambut.

\section{Pelayanan}

Pelayanan sudah banyak di tulis oleh Para Ahli terutama dalam bidang Pemasaran. Seperti yang dikatakan oleh Barrie Hopson dalam bukunya "12 Langkah Menuju Sukses Melalui Pelayanan Bermutu", bahwa kualitas pelayanan yang sampai pada konsumen, di mulai dari kualitas pelayanan yang saling diberikan oleh staf kepada rekannya (Barrie Hopson dan Mike Scally, 1995). Menurut Wyckof menyatakan pelayanan adalah tingkat keunggulan dan keinginan

pelanggan serta ketepatan penyampaiannya untuk mengimbangi harapan pelanggan (Mts. Arief, 2007).

Pada saat ini, hampir setiap musim haji selesai, selalu diiringi dengan munculnya berbagai keluhan jama'ah terhadap penyelenggaraan haji. Keluhan yang paling sering dilontarkan jama'ah berkaitan pelayanan petugas, akomodasi dan konsumsi selama di Arab Saudi dan kegiatan bimbingan manasik yang dirasakan belum memadai. Tuntutan masyarakat, khususnya para calon haji selanjutnya setelah BPIH 2006 mengalami kenaikan adalah peningkatan pelayanan kepada jama'ah haji, baik selama mereka di Tanah Air, maupun ketika melaksanakan ibadah haji di Arab Saudi. Sesuai dengan UndangUndang No.17 Tahun 1999, pasal 5, penyelenggaraan ibadah haji bertujuan untuk memberikan pembinaan, pelayanan dan perlindungan yang sebaikbaiknya melalui sistem dan manajemen penyelenggaraan yang baik agar pelaksanaan ibadah haji dapat berjalan dengan aman, tertib, lancar dan nyaman sesuai dengan tuntunan agama, sehingga jama'ah dapat melaksanakan ibadah secara mandiri dan memperoleh haji mabrur.

\section{Selayang Pandang Kabupaten Kuantan Singingi}

Kabupaten Kuantan Singingi (Kuansing) adalah salah satu kabupaten di Povinsi Riau, Indonesia Kabupaten Kuansing disebut pula dengan rantau Kuantan atau sebagai daerah perantauan orang-orang Minangkabau (Rantau nan Tigo Jurai). Dalam kehidupan sehari-hari, masyarakat Kuansing menggunakan adat istiadat serta bahasa Minangkabau. Kabupaten Kuantan Singingi pada awalnya merupakan bagian dari Kabupaten Indragiri Hulu, namun setelah dikeluarkannya Undang-undang Nomor 53 tahun 1999, Kabupaten Indragiri Hulu dimekarkan menjadi 2 ( dua ) kabupaten yaitu Kabupaten Indragiri Hulu dan 
Kabupaten Kuantan Singingi dengan Ibu Kotanya berkedudukan di Teluk Kuantan.

Setelah dilakukan Pemekaran Wilayah, Kuantan sekarang berada di Kabupaten Kuantan Singingi (Kuansing), yang ber-Ibu Kota Taluk Kuantan.Daerah ini lebih dikenal dengan sebutan 'Rantau Kuantan' yang terdiri dari 4 empat kecamatan, yaitu Kecamatan Kuantan Mudik, Kuantan Tengah, Kuantan Hilir dan Kecamatan Cerenti (Sekarang dimekarkan menjadi 13 Kecamatan). Berdasarkan penelitian yang dilakukan Ruswan et.al, ada empat kemungkinan tentang penamaan 'Kuantan' ini.

Pertama, sejarah Asal Mula Kuantan berasal dari kata 'Aku + Antan'. Aku berarti pancang batas daerah ini dengan alu (antan). Kedua, Asal Mula nama Kuantan bermula dari 'Kuak + Tuk Atan'. Kuak berarti rintisan, Tuk Atan adalah nama orang. Jadi Kuantan berarti daerah rintisan yang dilakukan oleh Tuk Atan. Ketiga, sejarah nama itu berawal dari 'Akuan + Sultan' yang lama-lama menjadi Kuantan. Keempat, asal Mulanya ialah, Kuantan berasal dari Bahasa Parsi yang berarti 'Banyak Air-air.

Dari keempat kemungkinan itu lah yang sampai saat ini diyakini sebagai Asal Mula nama "Kuantan". Orang Kuantan menggunakan 'Bahasa Melayu Dialek Kuantan' sebagai bahasa perhubungan. Mereka sangat fanatik dalam mempergunakan bahasa daerahnya. Orang Kuantan yang berada di luar daerahnya jika bertemu dengan sesama, akan mempergunakan Bahasa Melayu Dialek Kuantan itu, yang masih erat hubungannya dengan Bahasa-bahasa Melayu di wilayah Provinsi Riau lainnya. Agama yang dianut orang Kuantan adalah Agama Islam. Mereka sangat mementingkan pendidikan yang tidak ketinggalan jika dibandingkan orangorang Riau lainnya. Sebagian besar orang Kuantan bermata pencaharian petani (padi), peternak (sapi/kerbau), nelayan, buruh, pedagang, PNS dan lainnya.
Tradisi budaya dan sastra banyak dijumpai di Rantau Kuantan. Pacu Jalur merupakan tradisi yang sangat disukai orang-orang Rantau Kuantan. Olahraga Tradisional Pacu Sampan panjang ini merupakan tradisi yang sudah lama dijumpai di Rantau Kuantan. Selain itu Rantau Kuantan juga kaya akan tradisi Sastra. Misalnya Kayat, Koba (Kaba atau Nyanyian Panjang), Pantun Seratus, Rarak dan Randai. Melalui Randai banyak cerita yang disampaikan. Pantun Seratus merupakan pantun yang diciptakan secara spontanitas, yang lahir begitu saja sesuai situasi dan tuntutan pada saat berpantun. Demikian juga dengan kabiasaan bercerita, telah disampaikan secara turun temurun.

Pacu Jalur merupakan festival tahunan terbesar untuk masyarakat daerah kabupaten Kuantan Singingi khususnya pada ibu kota kabupatennya yaitu Taluk Kuantan yang berada di sepanjang sungai Kuantan. Pada awalnya di maksudkan sebagai acara memperingati hari-hari besar umat Islam seperti Maulid Nabi, ataupun peringatan tahun baru Hijriah. Namun setelah kemerdekaan Indonesia, festival pacu jalur ini ditujukan untuk merayakan Hari Ulang Tahun Kemerdekaan Republik Indonesia Indonesia. Pacu Jalur adalah perlombaan mendayung perahu panjang, semacam perlombaan Perahu naga di negeri tetangga Malaysia dan Singapura, yaitu sebuah perahu atau sampan yang terbuat dari kayu pohon yang panjangnya bisa mencapai 25 hingga 40 meter. Di daerah Taluk Kuantan sebutan untuk perahu panjang tersebut adalah Jalur. Adapun tim pendayung perahu (jalur) ini berkisar antara 50 - 60 orang.

Sebelum acara puncak "Pacu Jalur' ini dimulai, biasanya di adakan acara-acara hiburan rakyat berupa tarian dan nyanyian untuk menghibur seluruh peserta dan masyarakat sekitar, terutama yang berada di Teluk Kuantan. Pada acara Festival Pacu Jalur tahun 2009 
yang lalu, mulai di perkenalkan oleh Pemerintah Daerah setempat istilah "Jalur" Expo 2009, yaitu sebuah acara Pekan Raya berkaitan dengan Festival Pacu Jalur tersebut.

Tradisi pacu jalur yang diadakan sekali setahun pada peringatan perayaan hari kemerdekaan Indonesia menjadikan kota Taluk Kuantan sebagai tujuan wisata nasional. Perlombaan perahu panjang yang berisi lebih kurang 60 orang di sungai Kuantan ini biasanya diikuti masyarakat setempat, kabupaten tetangga, bahkan juga ikut pula pesertapeserta dari negara-negara tetangga seperti Malaysia, Singapura dan Thailand.Beberapa kawasan wisata lainnya seperti Tambang Emas di Logas, Arung Jeram di Sungai Singingi dan Pangkalan Indarung, Hutan Lindung Bukit Bungkuk dan Bukit Baling di Singingi, Gua Bunian di Bukit Kanua, kawasan Hiking dan Tracking di Bukit Batabuah. Rumah Tradisional Tua Koto Rajo, Kompleks Candi Sangan.

Berdasarkan hasil olahan data tentang maka dapat diketahui kepuasan jama'ah haji dalam proses pelayanan haji di Kabupaten Kuantan Singingi adalah "Sangat Puas" mencapai $83.82 \%$. baik dari segi pengolaan ibadah haji pada hakikatnya merupakan bentuk pelayanan kepada masyarakat. Dalam kaitan pengelolaan ibadah haji ada tiga bentuk pelayanan yang mesti di berikan, yakni pelayanan pembinaan manasik haji baik sebelum dan sesudah penyelenggaraan ibadah haji, pelayanan transportasi, pelayanan pemondokan, ktering, dan kesehatan.

Faktor-faktor yang mempengaruhi ibadah haji terhadap pelaksanaan ibadah haji (Studi kasus di kabupaten Kuantan Singingi) Jasa yang diharapkan/ dirasakan (expected service) : perasaan senang dalam merasakan pelayanan yang baik atau harapan-harapan nasabah terpenuhi. Terdapat sepuluh factor utama yang mempengaruhi harapan pelanggan terhadap suatu jasa yaitu (1) enduring service intensifiers,

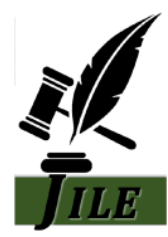

berupa harapan yang di sebabkan oleh orang lain dan filosofi pribadi seseorang mengenai suatu jasa; (2) kebutuhan pribadi, meliputi kebutuhan fisik, social, dan psikologis; (3) transitory service intensifiers, terdiri atas situasi darurat yang membutuhkan jasa tertentu (seperti asuransi kesehatan dan asuransi kecelakaan) dan jasa terakhir yang pernah dikonsumsi pelanggan; (4) persepsi pelanggan terhadap tingkat layanan perusahaan lain; (5) selfperceiped service role, yaitu persepsi pelanggan terhadap tingkat keterlibatannya dalam proses penyampaian jasa; (6) faktor situsional yang berada diluar kendali penyedia jasa; (7) janji layanan eksplitit, baik berupa iklan, personal selling, perjanjian maupun komunikasi dengan karyawan penyedia jasa; (8) janji layanan implisit, yang tercermin dari harga dan sarana pendukung jasa; (9) word of mouth, baik dari teman, keluarga, rekan kerja pakar maupun publikasi media massa; dan (10) pengalaman masa lampau. Jasa yang dipersepsikan (perceived service) : pandangan atau pemikiran nasabah tentang apa yang dilihat dan dirasakan. Sebagai pihak yang membeli dan mengkonsumsi jasa, pelangganlah yang menilai tingkat kualitas jasa sebuah perusahaan. Sayangnya, jasa memiliki karakteristik variability sehingga kinerja acapkali tidak konsisten. Hal ini menyebabkan pelanggan menggunkan isyarat intrinsic (output dan penyampaian jasa) dan isyarat ekstrinsik (unsur-unsur pelengkap jasa) sebagai acuan atau pedoman dalam mengevaluasi kualitas jasa.

Penglolaan ibadah haji pada hakikatnya merupakan bentuk pelayanan kepada masyarakat. Dalam kaitan pengelolaan ibadah haji ada tiga bentuk pelayanan yang mesti diberikan, yakni pelayanan pembinaan manasik haji sebelum dan sesudah penyelenggaraan ibadah haji, pelayanan transportasi, 
pelayanan pemondokan, katering dan kesehatan.

Sebagai bentuk pelayanan publik pengelolaan Ibadah Haji seyogyanya didasarkan pada asas: kepentingan umum, kepastian hukum; kesamaan hak; keseimbangan hak dan kewajiban; keprofesionalan; partisipatif; persamaan perlakuan/ tidak diskriminatif; keterbukaan; akuntabilitas; fasilitas dan perlakuan khusus bagi kelompok rentan; ketepatan waktu; dan kecepatan, kemudahan, dan keterjangkauan (Undang-Undang Nomor 25 Tahun 2009).

Di samping itu, pengelolaan ibadah haji juga harus memperhatikan hak-hak jama'ah haji sebagaiman dijamin dalam undang-undang perlindungan konsumen. Dalam undang-undang perlindungan konsumen, disebutkan bahwa hak konsumen itu adalah :

a) Hak atas kenyamanan, keamanan, dan keselamatan dalam mengkonsumsi barang dan/atau jasa.

b) Hak untuk memilih barang dan/atau jasa serta mendapatkan barang dan/atau jasa tersebut sesuai denga nilai tukar dan kondisi serta jaminan yang dijanjikan.

c) Hak atas informasi yang benar, jelas, dan jujur mengenai kondisi barang dan/atau jasa;

d) Hak untuk di dengar pendapat dan keluhannya atas barang dan/atau jasa yang digunakan;

e) Hak untuk mendapatkan advokasi, pelindungan, dan upaya penyelesaian sengketa perlindungan konsumen secara patut;

f) Hak untuk mendapat pembinaan dan pendidikan konsumen;

g) Hak untuk diperlukan atau dilayani secara benar dan jujur serta tidak diskriminatif;

h) Hak untuk mendapatkan kompensasi, ganti rugi dan/atau penggantian, apabila barang dan/atau jasa yang diterima tidak sesuai dengan perjanjian atau tidak sebagaimana mestinya;

i) Hak-hak yang diatur dalam ketentuan peraturan perundangundangan lainnya.

Pengorganisasian: keniscayaan pembentukan lembaga/badan khusus secara ideal, pengelolaan ibadah haji seyogyanya diorganisasikan oleh satu badan secara khusus melayani penyelenggaraan ibadah haji dan pengelolaan keuangan haji. Badan ini hendaknya diberi wewenang yang cukup besar, karena akan mengelola pekerjaan yang cukup besar pula, yakni menyelenggarakan ibadah haji mulai dari pendaftaran jama'ah haji, penentuan kuota, pelayanan administrasi keimigrasian, pemeriksaan kesehatan, pembimbingan manasik haji, pemberangkatan, pelayanan transportasi darat dari kota asal ke kota embarkasi, pemeriksaan kelengkapan administratif di asrama haji, pelayanan transportasi udara: penerbangan ke saudi arabia, pelayanan transportasi darat di Saudi Arabia, pelayanan pemondokan, dan pelayanan katering, pembimbingan ibadah di Saudi Arabia, dan terakhir pemulangan jama'ah haji.

Lembaga penyelengaraan ibadah haji adalah Badan Haji Indonesia, yang merupakan lembaga pemerintah, mempunyai perwakilan tetap, dibawah presiden, diawasi bersama DPR, seperti halnya BNP2TKI (Badan Nasional Penempatan dan Penempatan dan Perlindungan Tenaga Kerja Indonesia). Badan Haji Indonesia sebaiknya memiliki pesawat sekitar 10-20 buah dalam rangka meminimalisir. Biaya Penyelenggara Ibadah Haji (BPIH), yang dikelola secara profesional, dan diperuntukkan bagi 
calon jama'ah haji dan umrah. Pendapat di atas didukung oleh beberapa pendapat lainnya, yaitu pendapat dari Ikatan Persaudaraan Haji Indonesia (IPHI). IPHI menyatakan bahwa penyelenggara ibadah haji yang baik, diperlukan adanya badan khusus dibawah Presiden sebagai Lembaga Pemerintah Non Kementrian (LPNK) sebagai penyelenggara ibadah haji.

Pendapat yang sama juga disampaikan oleh Azyumardi Azra yang menyatakan bahwa penyelenggara Ibadah Haji dapat berupa sebuah Badan Khusus/lembaga negara, seperti Badan Otoritas Ibadah Haji (BOIH). Badan tersebut dibentuk pemerintah bersama dengan DPR RI dan memiliki hubungan koordinatif, evaluatif, dan supervisi dengan Kementrian Agama RI. Pendapat lain yang senada dengan pendapatpendapat sebelumnya juga disampaikan oleh Ichsanuddin Noorsy. Menurutnya perlu ada restrukturasi kelembagaan berbentuk Badan penyelenggara Haji Indonesia (BPHI) yang terdiri atas (1) Pelaksana (2) Bank Investasi Haji Syariah (3) Bank Investasi Haji Syariah (4) Dewan Pengawas Bank Bank Investasi Haji Syariah, Menteri sebagai Ketua Dewan Pengawas BPHI.

Selain pendapat-pendapat di atas, Abdul Gani Abdullah juga memandang perlunya pembuatan cabang kekuasaan yang memisahkan peran eksekutor penyelenggara ibadah haji dari regulator atau legal policy penyelengara ibadah haji serta peran evaluator akan efektif jika menyatu/melekat dengan regulator karena selama ini regulasi dan eksekusi serta evaluasi penyelenggara ibadah haji dilakukan oleh Kementrian Agama RI/Pemerintah, dimana hal ini akan memunculkan abuse of power. Abdul Gani juga mengusulkan adanya Badan Penyelenggara Haji Indonesia yang memiliki tugas menyiapkan perangkat penyelenggara, pembiayaan dan pelaporan pelaksanaan penyelenggaraan ibadah haji. Badan Penyelenggara Haji
Indonesia memiliki

hubungan kontraktual dengan calon jama'ah haji yang telah menyetor uang ke Bank Penerima Setoran ONH.

Usulan terkait dengan kelembagaan yang tidak jauh berbeda selanjutnya juga dikemukakan oleh Abdul Kholiq Ahmad. Menurutnya permasalahan dalam penyelenggara ibadah haji lebih dilatarbelakangi oleh menyatunya fungsi regulasi dan operasi bagi penyelenggara iadah haji, pelaksana PIH yang dilakukan oleh badan ad hoc, serta pengelolaan dana haji dan aset haji yang tidak transparan. Agar penyelenggara berbentuk Badan Khusus yang merupakan Lembaga Pemerintah Non Kementerian (LPNK), berada di bawah presiden, bertanggungjawab kepada presiden, serta mempunyai perwakilan tetap di provinsi, kabupaten/kota dan Arab Saudi, Badan Khusus ini merupakan lembaga pemerintah dan bukan swasta.

Kepuasaan pelanggan adalah sebuah hal yang teramat penting. Meskipun tidak muncul dalam neraca, namun sebenarnya itu adalah asset bisnis yang sangat berharga bagi perusahaan. Pelanggan yang puas akan memberikan banyak keuntungan bagi perusahaan. Mereka menjadi sarana promosi ampuh bagi produk dan jasa yang ditawarkan perusahaan. Pelanggan yang puas, akan cenderung bercerita tentang kepuasaan mereka mengkonsumsi produk dan jasa kita kepada kenalan, teman, sahabat dan sanak keluarga.

Tetapi menurut Cahyo Pramono mengatakan kepuasaan pelanggan bukanlah segalanya. Kepuasaan pelanggan tidak bermakna si pelanggan akan loyal atau akan mengeluarkan banyak uang demi pelayanan kita. Tingkat kepuasaan pelanggan adalah suatu hal yang terus bergerak. Ia bersifat situsional, cenderung berubah setiap waktu. Bisa saja saat ini si konsumen puas, tetapi belum tentu besoknya puas. Atau sebaliknya, mengaku tidak puas, 
tetapi rutin menggunakan produk/jasa itu. Begitu pula dengan pelayanan yang diberikan oleh KBIH Bryan Makkah, apabila kinerja pembimbing memberikan pelayanan sesuai yang diharapkan para jama'ah, maka jama'ah akan merasa puas atas kinerja pembimbing.

Kepuasan hanyalah indikasi awal yang menunjukkan hubungan antara produsen dan konsumen. Kesalahan yang dilakukan oleh banyak produsen dan pemasar adalah secra berlebihan fokus memburu kepuasaan pelanggan saja, tanpa memperhatikan pola kepuasaan pelanggan yang berkelanjutan sebagai bagian dari pembuka pintu keuntungan. Untuk bisa tetap mendapatkan keuntungan berkelanjutan, maka produsen dan pemasar pun harus bisa tetap mengikuti dan menyesuaikan perkembangan itu. Untuk itu, produsen atau pemasar sangat penting melakukan berbagai studi untuk memahami konsumennya. Harus ada proses pemahaman perilaku, kebiasan, dan keinginan konsumen. Survey langsung kepada konsumen akan membantu produsen dan pemasar melihat sisi nyata produknya.

a. Jasa yang diharapkan/dirasakan (expected service) : perasaan senang dalam merasakan pelayanan yang baik atau harapanharapan nasabah terpenuhi. Terdapat sepuluh factor utama yang mempengaruhi harapan pelanggan terhadap suatu jasa yaitu (1) enduring service intensifiers, berupa harapan yang di sebabkan oleh orang lain dan filosofi pribadi seseorang mengenai suatu jasa; (2) kebutuhan pribadi, meliputi kebutuhan fisik, sosial, dan psikologis; (3) transitory service intensifiers, terdiri atas situasi darurat yang membutuhkan jasa tertentu (seperti asuransi kesehatan dan asuransi kecelakaan) dan jasa terakhir yang pernah dikonsumsi pelanggan; (4) persepsi pelanggan terhadap tingkat layanan perusahaan lain; (5) self-perceiped service role, yaitu persepsi pelanggan terhadap tingkat keterlibatannya dalam proses penyampaian jasa; (6) faktor situsional yang berada diluar kendali penyedia jasa; (7) janji layanan eksplitit, baik berupa iklan, personal selling, perjanjian maupun komunikasi dengan karyawan penyedia jasa; (8) janji layanan implisit, yang tercermin dari harga dan sarana pendukung jasa; (9) word of mouth, baik dari teman, keluarga, rekan kerja pakar maupun publikasi media massa; dan (10) pengalaman masa lampau.

b. Jasa yang dipersepsikan (perceived service) : pandangan atau pemikiran nasabah tentang apa yang dilihat dan dirasakan. Sebagai pihak yang membeli dan mengkonsumsi jasa, pelangganlah yang menilai tingkat kualitas jasa sebuah perusahaan. Sayangnya, jasa memiliki karakteristik variability sehingga kinerja acapkali tidak konsisten. Hal ini menyebabkan pelanggan menggunkan isyarat intrinsic (output dan penyampaian jasa) dan isyarat ekstrinsik (unsur-unsur pelengkap jasa) sebagai acuan atau pedoman dalam mengevaluasi kualitas jasa.

\section{KESIMPULAN}

Berdasarkan hasil olahan data tentang maka dapat diketahui kepuasan jama'ah haji dalam proses pelayanan haji di Kabupaten Kuantan Singingi adalah "Sangat Puas" mencapai $83.82 \%$. baik dari segi pengolaan ibadah haji pada hakikatnya merupakan bentuk pelayanan kepada masyarakat. Dalam kaitan 
pengelolaan ibadah haji ada tiga bentuk pelayanan yang mesti di berikan, yakni pelayanan pembinaan manasik haji baik sebelum dan sesudah penyelenggaraan ibadah haji, pelayanan transportasi, pelayanan pemondokan, ktering, dan kesehatan.

Faktor-faktor yang mempengaruhi ibadah haji terhadap pelaksanaan ibadah haji (Studi kasus di kabupaten Kuantan Singingi) Jasa yang diharapkan/dirasakan (expected service) : perasaan senang dalam merasakan pelayanan yang baik atau harapanharapan nasabah terpenuhi. Terdapat sepuluh factor utama yang mempengaruhi harapan pelanggan terhadap suatu jasa yaitu (1) enduring service intensifiers, berupa harapan yang di sebabkan oleh orang lain dan filosofi pribadi seseorang mengenai suatu jasa; (2) kebutuhan pribadi, meliputi kebutuhan fisik, social, dan psikologis; (3) transitory service intensifiers, terdiri atas situasi darurat yang membutuhkan jasa tertentu (seperti asuransi kesehatan dan asuransi kecelakaan) dan jasa terakhir yang pernah dikonsumsi pelanggan; (4) persepsi pelanggan terhadap tingkat layanan perusahaan lain; (5) self-perceiped service role, yaitu persepsi pelanggan terhadap tingkat keterlibatannya dalam proses penyampaian jasa; (6) faktor situsional yang berada diluar kendali penyedia jasa; (7) janji layanan eksplitit, baik berupa iklan, personal selling, perjanjian maupun komunikasi dengan karyawan penyedia jasa; (8) janji layanan implisit, yang tercermin dari harga dan sarana pendukung jasa; (9) word of mouth, baik dari teman, keluarga, rekan kerja pakar maupun publikasi media massa; dan (10) pengalaman masa lampau. Jasa yang dipersepsikan (perceived service) : pandangan atau pemikiran nasabah tentang apa yang dilihat dan dirasakan. Sebagai pihak yang membeli dan mengkonsumsi jasa, pelangganlah yang menilai tingkat kualitas jasa sebuah perusahaan. Sayangnya,

jasa memiliki karakteristik variability sehingga kinerja acapkali tidak konsisten. Hal ini menyebabkan pelanggan menggunkan isyarat intrinsic (output dan penyampaian jasa) dan isyarat ekstrinsik (unsur-unsur pelengkap jasa) sebagai acuan atau pedoman dalam mengevaluasi kualitas jasa.

\section{REFERENSI}

Abd al-Rahman al-Jaziri, Kitab al-Fiqh, ala al-Madzahib al-Arba'ah, 1-5 Lebanon: Dar al-Kutub alIlmiyah, 2010

Ahmad Nidjam dan Alatief Hanam, Manajemen Haji studi kasus dan telaah implementasi knowledge workers, Jakarta: Zikrul hakim, 2010

Ali Hasan, Tuntunan Haji, Jakarta: PT Raja Grafindo Persada, Cet ke 2, 2010

Al-Qadhi Abi al-Walid Muhammad bin Ahmad bin Muhammad bin Ahmad Ibn Rusyd al-Qurtubi alAndalusi, Bidayatul Mujtahid wa Nihayat alMuqtashid Libanon: Dar al-Kutub al-Ilmiya, 2007

Al-Sayyid Sabiq, Fiqh al-Sunnah Mesir: al-Fath lil A'lam al-Arabi, 2004

Anshori Umar, Fiqh Wanita, Semarang: CV. Asy-Syifa, 1986

Armen J. Kabodian terjemah A. Hadyana Pudjaatmaka, Pelanggan Selalu Benar, Jakarta: Arcan, 1998

Barrie Hopson dan Mike Scally terjemah Danuyasa A, 12 Langakah Menuju Sukses Melalui Pelayanan Bermutu, Jakarta: Arcan, 1995

Burhan Bugin, Metode Penelitian Kualitatif, Jakarta: PT. Grafindo Persada, 2000

Cahyo Pramono, "Kepuasaan Pelanggan Bukanlah Segalanya", Harian Waspada, 17 September 2007, hal. ekonomi, www.cahyonopramono.com/2007/0 9/kepuasan-pelanggan-bukansegalanya.html 
Depag RI. Al-Qur'an dan Terjemahannya, Surabaya: Surya Cipta. 1993

Dikrokrat Pembinaan Perguruan Tinggi Agama islam, Ilmu Fiqh, Jakarta: Cet: Andi, 2000

Fandy Tjiptono, Persfektif Manajemen Dan pemasaran Kontemporer, (Yogyakarta: Andi, 2000

Ibnu Hajar Al-Haitaimi, Syarah Fathul Mui'n, Semarang: Pustaka alAmaliyah, t.th

Ihwan, et al, Ekslopedia Haji dan Umroh, Jakarta: PT Raja Grafindo Persada, 2000

Imam Taqiyuddin, Khifayatul Akhyar, Surabaya: Darul Islami, t.th

Kementrian Agama RI Badan Litbang dan Diklat Puslitbang Kehidupan Keagamaan, 2009

Mahmud Anwar, Tuntunan Ibadah Haji dan Umroh, Bandung: Sinar Baru Algensindo, 2004

R. Abdul Jamil, Hukum Islam, Mandar Maju: Bandung: 1992

Mts. Arief, Pemasaran Jasa dan Kualitas Pelayanan,Malang: Banyumedia Publishing, 2007

Muhammad bin Ismail, Subul As-Salam, Bairut: Dar Al-Kutub Al-amaliah, Juz II, Cet Ke I, 1998

Muhammad Bagir al-Habsy, Fiqih Praktis Menurut Al-Qur'an, Hadis dan Pendapat Ulama, Bandung: Mizan, 1999

Philip Kotler, Manajemen Pemasaran:Analisis, Perencanaan, Implementasi dan Control, Jakarta: PT. Prenhallindo

Sugiyono, Metode Penelitian Pendidik, Bandung: Alfabeta, 2008

Suharsimi Arikunto, Prosedur Penelitian Suatu Pendekatan Praktek Jakarta: Rineka Cipta, 2013

Tengku Muhammad Hasby ash Shiddieqy, Pedoman Haji, Semarang: Pt: Pustaka Rizki Putra, 2000

Undang-Undang Nomor 25 Tahun 2009 tentang Pelayan Publik

WJS Poerdarminta, Kamus Umum Bahasa Indonesia, Jakarta: PN. Balai Pustaka, 1976
Yeni, "Analisis Hubungan Pelayanan, Fasilitas, Dan Harga Dengan Tingakat Kepuasaan Konsumen di PT. Trimitra (penyelenggara umroh dan haji) Surabaya" Skripsi, Fakultas Dakwah IAIN Sunan Ampel Surabaya, 2001 